\title{
In vitro investigation of King Oyster Mushroom [Pleurotus eryngii (DC.: Fr.) Quél.] strains in vegetative growing phases
}

\author{
Szarvas, J. ${ }^{1}$, Naár, . $^{2}$, Geösel, A. ${ }^{3}$ \& Györfi, J. ${ }^{3}$ \\ ${ }^{I}$ Eszterházy Károly College, Department of Biochemistry and Food Chemistry, \\ Hungary-3300 Eger, Leányka u. 6-8.
}

${ }^{2}$ Eszterházy Károly College, Department of Microbiology and Food Technology, Hungary - 3300 Eger, Leányka u. 6-8. ${ }^{3}$ Corvinus University of Budapest, Faculty of Horticultural Science, Department of Vegetable and Mushroom Growing. Hungary - 1118 Budapest, Villányi út 29-43.

Summary: The king oyster mushroom (Pleurotus eryngii) is more and more popular amongst the producers due to its excellent taste and relatively easy cultivation. In the course of our work we collected 15 king oyster mushroom strains from various habitats in Hungary in order to get a better picture about the growth of the vegetative mycelia of the species and its different strains. In the in vitro experiments we investigated the growth of the strains at various temperatures and $\mathrm{pH}$, incubated them in light and darkness and in aerobic and anaerobic atmosphere. In addition to these we measured the weight of dry mycelia produced in a given time by the strains. Our results showed that the above mentioned environmental conditions resulted in a very different growth rate of the vegetative mycelia of the various $P$. eryngii strains. These results may provide valuable data about the vegetative phase of the cultivation.

Key words: Pleurotus eryngii, vegetative mycelium, temperature, $\mathrm{pH}$, light, anaerobic tolerance.

\section{Introduction}

Edible mushrooms are low energy foods with high nutritional value at the same time. Though their role in the healthy, reform and dietetic nourishment is significant, mushroom consumption in Hungary is still not remarkable. The volume of mushroom consumption in Hungary has been stagnated for years and the amount of the produced mushroom decreases steadily from year by year. While 35.000 tons of mushrooms were produced in 1993, in 2008 only $20.000-22.000$ tons were cultivated. Only 1.500 tons of oyster mushroom and 100 tons of shiitake mushroom (Lentinula edodes (Berk.) Pegler) is produced in Hungary recently, though the latter one is the most popular species in the world (Geösel et al., 2009). The champignon (Agaricus bisporus (J.E. Lange) Imbach), oyster mushroom (Pleurotus ostreatus (Jacq.) P. Kumm.) and shiitake mushroom ( $L$. edodes) compose only a narrow segment of the potentially cultivable mushrooms, so our aim is to involve more species into cultivation in Hungary. We think that amongst the potentially new mushroom species the king oyster mushroom (Pleurotus eryngii) bears extraordinary opportunities for cultivation and consumption.

Pleurotus species belong to the Pleurotaceae family, member of the Basidiomycota phylum. Common features of the Pleurotus species are the large fruiting body and the dry pileus, rarely with membranous veil. There is no gelatinous layer under the cortex of the pileus and the gills are whitish and run all the way from the stem. The stipes are mostly short and eccentric. The spore print is whitish and not amyloid. The spores are longish and have no germ pore. Gill trama is regular. There are white rot saprobic and parasitic species in the genus that degrade polymers of lignin and cellulose, as well (Gerhardt, 2007).

The Pleurotus eryngii is found in pastures, meadows, gardens and seldom in grassy forest clearings and hilly areas. The Pleurotus of the Umbellifers occupy an area in the Northern hemisphere between the 30 and $50^{\circ} \mathrm{N}$ (Zervakis \& Balis, 1996). These species are mainly found in the subtropical regions of the Mediterranean, Central Europe, Russia, Ukraine, Central Asia and Iran. The P. eryngii sensu lato is the only taxon within the genus, which grows in association with plants. This species complex includes facultative biotrophs, namely weak parasites on the roots and stems of Apiaceae (Umbelliferae) family (Eryngium, Ferula, Ferulago, Cachrys, Laserpitium, Diplotaenia, Elaeoselinum, Thapsia, Peucedanum etc.) (Zervakis et al., 2001; Rodriguez, 2008; Szili, 1994). This white rot species is mainly associated with Eryngium and Ferula species in Hungary. According to their association with plant taxons we expect at least two varieties, the $P$. eryngii var. eryngii and $P$. eryngii var. ferulae. In the Carpathian basin the species is relatively common and since it is cold-tolerant, it grows from May till 
November, but can be cropped mostly in autumn (OctoberNovember). The mushroom is reckoned as delicious, as shown by its English name 'king oyster mushroom'.

There are a lot of discrepancies in the judge of the taxonomic relationships of the host-specialized $P$. eryngii species complex. Many scientists consider most or all of the ecotypes as separate species (Joly et al., 1990; BoisselierDubayle, 1983), others consider them as varieties (Bresinsky et al., 1987; Hilber, 1982), whereas certain scientists take stand between the two opinions. In the literature the following taxons are kept count within the $P$. eryngii species complex: $P$. eryngii var. eryngii, $P$. eryngii var. ferulae, $P$. eryngii var. elaeoselini, $P$. eryngii var. nebrodensis, $P$. hadamardii, P. fossulatus (Venturella et al., 2000; Zervakis et al., 2001) and the newly described variety $P$. eryngii var. tingitanus (Lewinsohn et al., 2002; Rodriguez, 2008). The taxonomy debates could be ended by comprehensive molecular biology, speciation and co-evolutionary researches.

It is important to mention, that intensive production of the species started in Hungary in the 1950s, on mixture of composted hay and sawdust (Kalmár, 1960; Szili, 1994; Kirbag et al., 2008). Later on in the 1960s Véssey tried to produce the mushroom on sterile substrate (Véssey, 1971). Cailleux and Diop used sterile medium consisting of wheat straw and oat for the production (Cailleux et al., 1974). There are much more raw materials that can be used for cultivation, than those are mentioned in the literature. Most of these materials are based on agricultural and forestry wastes, such as straw of different grains, sawdust of certain kinds of woods, cotton-straw, soybean straw, corn stalk, Cyperus alternifolius stalk, corn flour, cooked grain seeds, malt, bamboo dust, cornmeal, ricebran etc. (Sawa, 1996; Ohga, 2000; Ohga, 1999; Ohga et al., 2004; Szarvas et al., 2002; Györfi et al., 2007). Different countries have to estimate what kind of cheap and easily accessible basic materials they can use for the production of the mushroom, in order to determine the composition of the substrate. The basic material can be produced either by wet heat treatment (xerotherm method) or by sterile technology (Kószó, 1997; Szarvas et al., 2002). A critical point in the preparation of the substrate is the adjustment of nitrogen content, since both the too low or too high level of nitrogen results a decrease in the amount of mushroom. The danger of supplementation is the emergence of various moulds (e.g. Trichoderma spp., Penicillium spp. etc.) on the blocks and later on the fruiting bodies.

Generally the cultivation is carried out in vessels or in plastic bags that contain 1-5 kg substrate, or from extruded basic material. The fruiting bodies develop from the free surface of the non-covered basic material or from the perforations of the bags. It is common that the same casing material is applied that is used for the cultivation of champignon (A. bisporus). Györfi \& Hajdú (2007) found significant yield increase compared to the non-cased cultures, when covering material mixes of different thickness were used. Another possible cultivation method is when the spawn run blocks are sunken $25-30 \mathrm{~cm}$ deep into the soil then covered by $3 \mathrm{~cm}$ of peat.
In the course of the intensive cultivation the climatic parameters can be set as shown in Table 1 .

Table 1. Growth parameters of P. eryngii by Stamets, 2000.

\begin{tabular}{|l|c|c|c|c|c|}
\hline & $\begin{array}{c}\text { Tempera- } \\
\text { ture }\left({ }^{\circ} \mathrm{C}\right)\end{array}$ & $\begin{array}{c}\text { Relative } \\
\text { humidity } \\
\mathrm{RH}(\%)\end{array}$ & $\begin{array}{c}\text { Duration } \\
\text { (day) }\end{array}$ & $\begin{array}{c}\mathrm{CO}_{2} \\
(\mathbf{p p m})\end{array}$ & $\begin{array}{c}\text { Light } \\
\text { require- } \\
\text { ments (lux) }\end{array}$ \\
\hline Spawn run & 24 & $90-95$ & $12-16$ & $\begin{array}{c}5.000- \\
20.000\end{array}$ & - \\
\hline $\begin{array}{l}\text { Primordia } \\
\text { formation }\end{array}$ & $10-15$ & $95-100$ & $4-5$ & $\begin{array}{c}500- \\
1.000\end{array}$ & $\begin{array}{c}500- \\
1.000\end{array}$ \\
\hline $\begin{array}{l}\text { Fruitbody } \\
\text { development }\end{array}$ & $15-21$ & $85-90$ & $4-8$ & $<2.000$ & $\begin{array}{l}500- \\
1.000\end{array}$ \\
\hline
\end{tabular}

The total yield can be harvested in two-three flushes from the same substrate.

Our knowledge was funded on the observation of the natural behaviour of the species, completed by experimental results. The aim of the recent work was to get a better understanding of the vegetative growth dynamism of the species and its strains and of the effects of the decisive environmental factors, as well.

Though this mushroom was first cultivated in Hungary, we totally forgot it. On the grounds of its gastronomic value and yield it would be necessary to concern with its cultivation more substantially. This species is grown in a large volume in China and also produced and consumed in Western-Europe (Italy, Spain and France). There will be huge opportunities in the production of the species, if strains of Hungarian origin are involved into growing and crossing and the production technology is adapted to the Hungarian basic materials. In the course of our work we tried to map the differences between the species of Hungarian origin in vitro, so we introduce the results of the first steps that lead to the mass-production.

\section{Materials and methods}

\section{Isolation of strains}

Isolations were performed from fruiting bodies collected from various grassy areas of Hungary. Inoculation onto malt agar plates was made by the use of plectenchyma originated from the broken pileus, then the plates were incubated on $25^{\circ} \mathrm{C}$. After incubation samples were taken from the regular sectors of the vegetative mycelia and inoculated three more times onto new agar plates.

\section{Maintenance of strains}

Vegetative mycelia were kept on slant of malt agar medium on $5{ }^{\circ} \mathrm{C}$. For long-term maintenance we used cryopreservation. Small discs were collected from the vegetative mycelia mat with cork borer and placed into freezer tubes that contained $10 \%$ glycerol solution. The freezer tubes were cooled by $1{ }^{\circ} \mathrm{C} /$ minute until $-40{ }^{\circ} \mathrm{C}$ then sunken in liquid nitrogen. 


\section{Investigation of the effect of temperature}

To perform the temperature experiments, 10 days old vegetative mycelial mats of 15 strains were inoculated into the centre of malt agar plates, one strain on each plate. The mycelial mats were collected by $0.8 \mathrm{~cm}$ diameter cork borer. Incubations were performed in the following temperatures: 5 ${ }^{\circ} \mathrm{C}, 10{ }^{\circ} \mathrm{C}, 15^{\circ} \mathrm{C}, 20^{\circ} \mathrm{C}, 25^{\circ} \mathrm{C}, 30^{\circ} \mathrm{C}$ and $35^{\circ} \mathrm{C}$. Incubations on each temperature were repeated three times with each strain, the control strains were grown on $25^{\circ} \mathrm{C}$. In addition to the collected strains in this experiment the Korona 357 (K 357 ) industrial hybrid strain, originated from the crossing of the popular Gyurkó HK 35 hybrid, was investigated, as well.

\section{Investigation of the effect of $\mathrm{pH}$}

$\mathrm{pH}$ of the malt agar plates was set between 4 and 9 in 0.5 steps by $1 \mathrm{M} \mathrm{HCl}$ or $1 \mathrm{M} \mathrm{NaOH}$. Inoculations were made the same way as in the temperature experiments in three replicates and the plates were incubated on $25^{\circ} \mathrm{C}$. The $\mathrm{pH}$ of the control malt agar plates was set to 6 , and the K 357 industrial hybrid was used as a control strain.

\section{Investigation of growth in light and dark}

The spawn run time can be effected by light. In this experiment malt agar plates with $\mathrm{pH} 6$ were used and inoculations were made in three replicates the same way as described above. Every strain was inoculated on 6 plates. 3 plates were incubated on $23{ }^{\circ} \mathrm{C}$ in dark; the other 3 plates were incubated on $23^{\circ} \mathrm{C}$ and lighted according to the normal daily light-dark periods. Colony diameter was measured on the seventh day.

\section{Investigation of dry mycelial weight}

Measurement of colony diameter is not always sufficient to determine the vegetative mycelial weight of the fungus, since thickness of aerial hyphae and substrate mycelia can be very different. Instead of cultivation in liquid medium we grew the strains on $8.5 \mathrm{~cm}$ diameter cellophane sheets, laid on malt agar. At first the clean cellophane sheets were dried on $105^{\circ} \mathrm{C}$ until constant weight, then their mass was measured. In the next step the sheets were sterilized in autoclave on 121 ${ }^{\circ} \mathrm{C}$ for 20 minutes and laid on malt agar plates. The strains were inoculated into the centre of the sheets and incubated for 7 days on $25^{\circ} \mathrm{C}$. After the incubation the cellophane sheets with the mycelia were removed from the agar plates and dried on $105{ }^{\circ} \mathrm{C}$ until constant weight. Total mass of the sheets and dry mycelia was measured and then mass of the sheets was subtracted, so the mass of the dry vegetative mycelia of identical age could be calculated.

\section{Anaerobic tolerance of mycelia}

The strains were inoculated into the centre of malt agar plates with $\mathrm{pH}$ 6. One strain was inoculated onto 6 plates.
The plates were incubated for 3 days on $25^{\circ} \mathrm{C}$ under normal atmospheric conditions to check the viability of inoculated mycelia. After incubation the colony diameters were measured, then 3 plates were placed into anaerobic jars and the other 3 plates were incubated under normal atmospheric conditions. In the jars the anaerobic atmosphere consisted of $10 \% \mathrm{H}_{2}, 10 \% \mathrm{CO}_{2}$ and $80 \% \mathrm{~N}_{2}$. The jars were placed into incubators on $25{ }^{\circ} \mathrm{C}$ and diameter of the colonies was measured after 7 days of incubation, in line with the colonies grown under normal atmospheric conditions. To get the exact growth rate, starting diameters measured right before the anaerobic/aerobic shared incubation were subtracted from the diameters measured at the end of the experiment.

At the single experiments we monitored the connection between the influencing factors by the calculation of the Spearman correlation coefficient. The value shows the tightness of connection and rate of variable. If the value is close to 1 , connection between the variables is tight, so the conditions strongly influence variation of the values. If the value is close to 0 , connection between the two variables is loose (Orbán, 1995).

\section{Results and discussion}

\section{Collections}

In the period of 2006-2008 we isolated 15 strains that were deposited in the strain collection of cultivable mushrooms of the Strain Research Laboratory of the Hungarian Mushroom Growers' Association (Demjén). Replica cultures are maintained in the Laboratory of Microbiology of the Eszterházy Károly College (Eger).

\section{Growth rate of vegetative mycelia on different temperatures}

Mycelia of the various strains showed very similar growth rate on minimum and maximum temperatures. In contrast to this, on optimal temperature significant differences of the growth rate were noticed. Since the optimal temperature range is used for spawn run in the course of cultivation, it is worth to determine the growth rate of strains (or hybrids) before mass production, because significant differences can be found between the strains (Figure 1-3). Table 2 shows the number of days certain strains needed to reach the maximum $8.5 \mathrm{~cm}$ colony diameter on a given temperature. Grey fields show the shortest time the strains needed to reach the maximum colony diameter and the most lowermost line gives a summary about the amount of those strains that reached the maximum diameter on the given temperatures. The results are summarized in Figure 4 and it shows clearly that $25^{\circ} \mathrm{C}$ is the optimal temperature for vegetative growing for the most strains. 


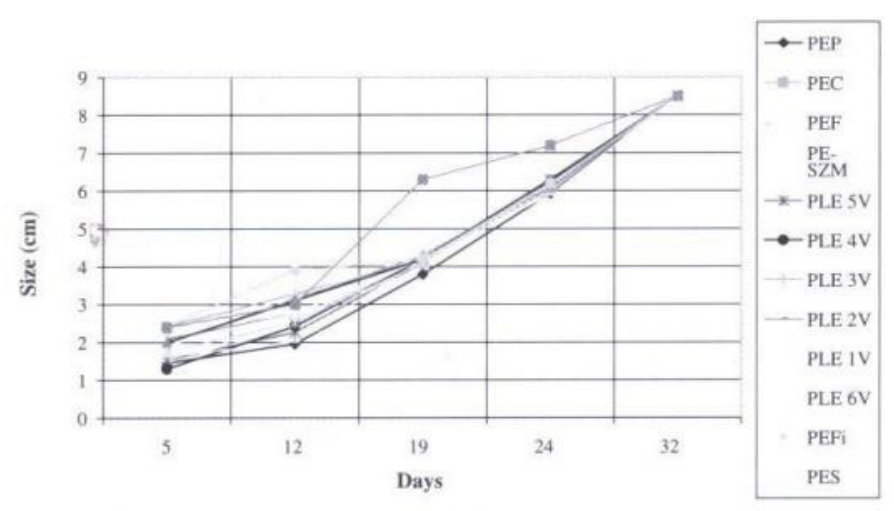

Figure 1. Growth rates of colonies on $10^{\circ} \mathrm{C}$.

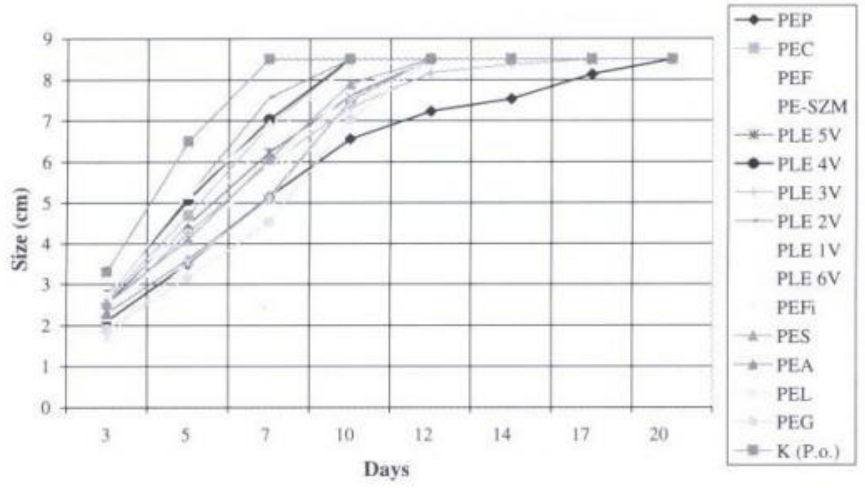

Figure 2. Growth rates of colonies on $20^{\circ} \mathrm{C}$.

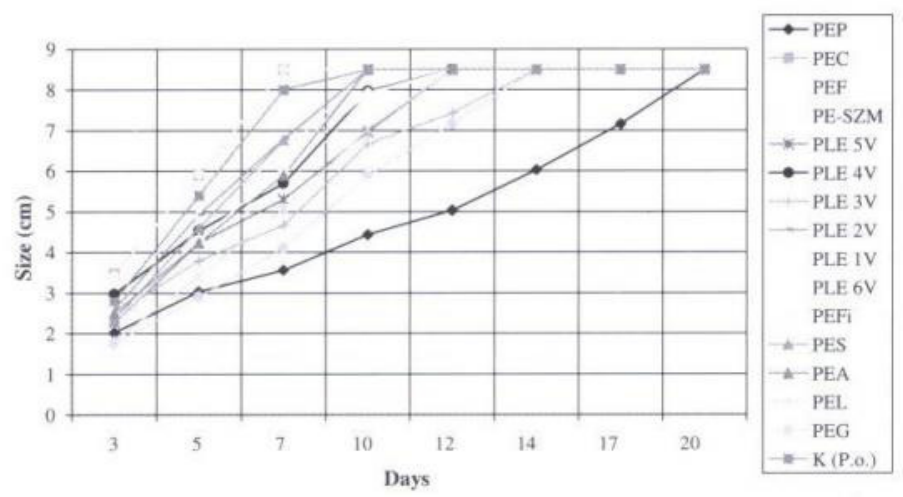

Figure 3. Growth rates of colonies on $25^{\circ} \mathrm{C}$.

Table 2. Time (days) required by the different strains to reach maximum colony diameter $(8.5 \mathrm{~cm})$ on certain temperatures. C: K 357 P. ostreatus hybrid control.

\begin{tabular}{|c|c|c|c|c|c|c|c|}
\hline Strain/Temp & $\mathbf{5}^{\circ} \mathbf{C}$ & $\mathbf{1 0}^{\circ} \mathbf{C}$ & $\mathbf{1 5}^{\circ} \mathbf{C}$ & $\mathbf{2 0}^{\circ} \mathbf{C}$ & $\mathbf{2 5}^{\circ} \mathbf{C}$ & $\mathbf{3 0}^{\circ} \mathbf{C}$ & $\mathbf{3 5}^{\circ} \mathbf{C}$ \\
\hline PEP & 41 & 32 & 24 & $\mathbf{2 0}$ & $\mathbf{2 0}$ & 23 & \\
\hline PEC & 41 & 32 & 24 & 10 & $\mathbf{7}$ & 10 & \\
\hline PEF & 41 & 32 & 24 & 12 & $\mathbf{1 0}$ & $\mathbf{1 0}$ & \\
\hline PE-SZM & - & 32 & 19 & $\mathbf{1 2}$ & $\mathbf{1 2}$ & $\mathbf{1 2}$ & - \\
\hline PLE 5V & 41 & 32 & 19 & $\mathbf{1 2}$ & $\mathbf{1 2}$ & $\mathbf{1 2}$ & \\
\hline PLE 4V & 41 & 32 & 14 & $\mathbf{1 0}$ & 12 & 12 & \\
\hline PLE 3V & 41 & 32 & 19 & 17 & 14 & $\mathbf{1 0}$ & \\
\hline PLE 2V & 41 & 32 & 14 & $\mathbf{1 0}$ & $\mathbf{1 0}$ & $\mathbf{1 0}$ & \\
\hline PLE 1V & 41 & 32 & 14 & $\mathbf{1 0}$ & $\mathbf{1 0}$ & $\mathbf{1 0}$ & \\
\hline PLE 6V & 41 & 32 & 19 & $\mathbf{1 2}$ & $\mathbf{1 2}$ & $\mathbf{1 2}$ & \\
\hline PEFi & 41 & 32 & 14 & 12 & $\mathbf{7}$ & 10 & \\
\hline PES & 41 & 32 & 14 & 12 & $\mathbf{1 0}$ & $\mathbf{1 0}$ & \\
\hline PEA & 41 & 32 & 19 & 12 & $\mathbf{1 0}$ & $\mathbf{1 0}$ & \\
\hline PEL & - & 32 & 24 & $\mathbf{1 2}$ & $\mathbf{1 2}$ & 17 & - \\
\hline PEG & 41 & 32 & 19 & $\mathbf{1 2}$ & 14 & 14 & - \\
\hline C (P.o.) & 41 & 32 & 10 & 7 & 10 & 10 & - \\
\hline Mean & 41.00 & 32.00 & 18.67 & 12.33 & 11.47 & 12.13 & \\
\hline Deviation & 0.000 & 0.000 & 3.994 & 2.717 & 3.137 & 3.603 & \\
\hline Prevalence & 0 & 0 & 0 & 9 & 12 & 9 & 0 \\
\hline
\end{tabular}

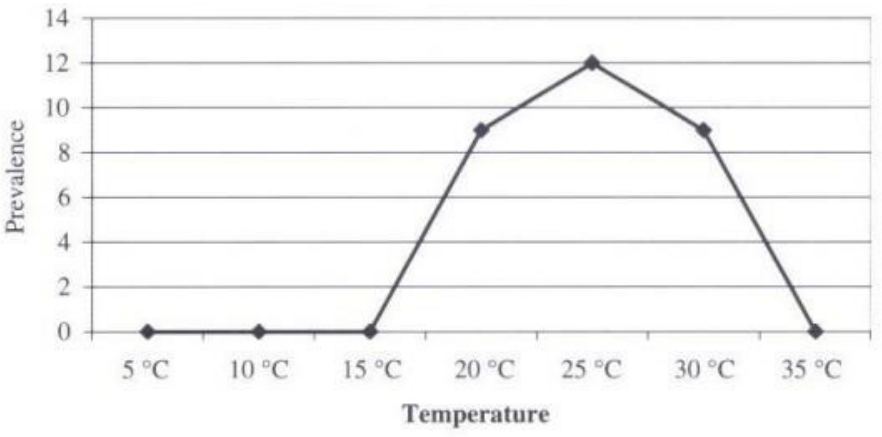

Figure 4. Average temperature optimum of 15 P. eryngii strains.

Pleurotus species have high $\mathbf{p H}$ tolerance, but significant differences in the optimum $\mathrm{pH}$ value were found between the certain strains. The $\mathrm{pH} 4$ is a strongly limiting value for some strains, whereas other strains grow almost at the same rate as at higher $\mathrm{pH}$ (Figure 5-7). It was surprising that some strains showed relatively fast growing on alkaline $\mathrm{pH}(8-9)$. This feature may be used for protection against competitive organisms and microparasites to avoid the use of pesticides.

Table 3 shows the connection between $\mathrm{pH}$ values and the time required for the strains to reach the maximum colony diameter. We found that the strains grew faster on two $\mathrm{pH}$ values: one optimum was at the acidic $\mathrm{pH} 4.5$, the other one was at the alkaline $\mathrm{pH} 7.5-8.5$ range (Figure 8 ). Since the result was obtained from the mean growth rate of 15 strains and the strains did not show significant differences, it is more characteristic for the species than for its different strains.
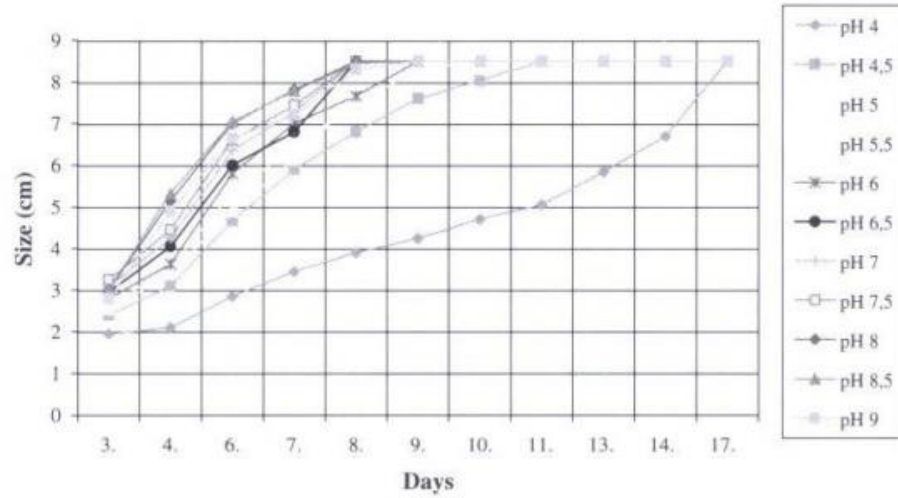

Figure 5. Growth rate of PEC strain on different $\mathrm{pH}$ values.
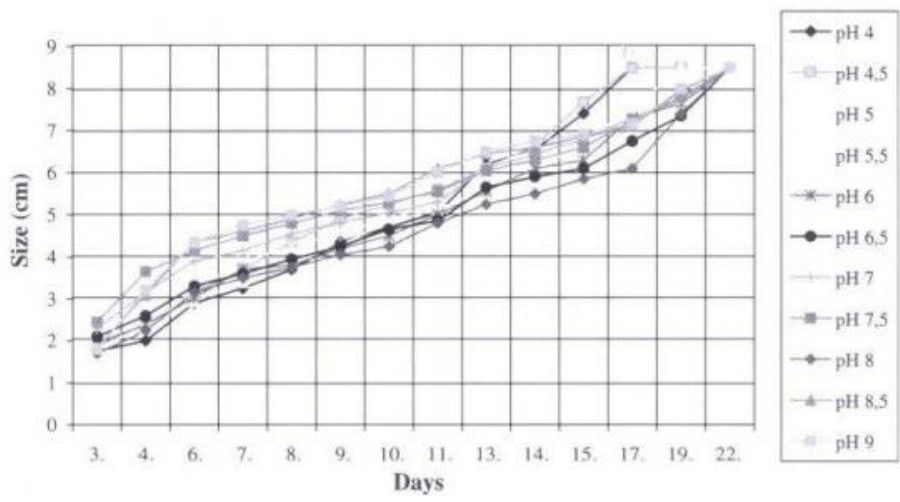

Figure 6. Growth rate of PEP strain on different $\mathrm{pH}$ values. 


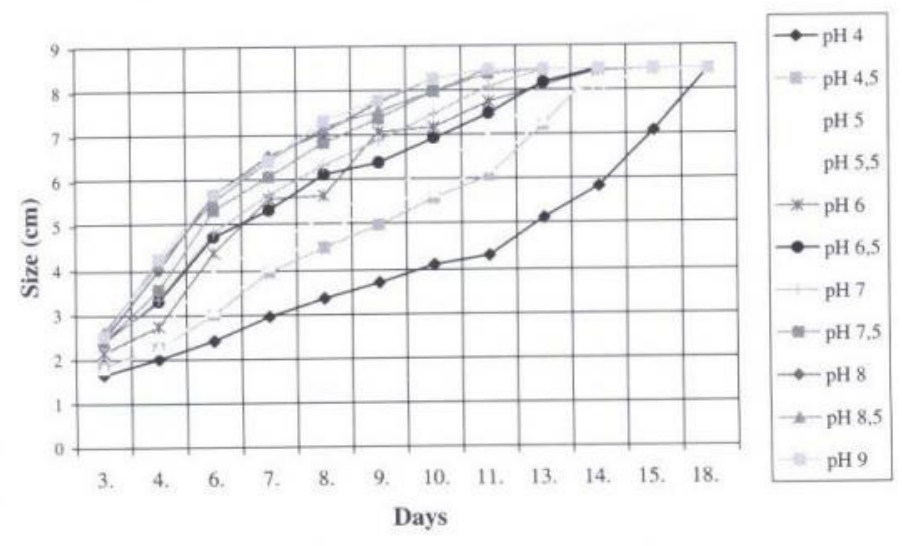

Figure 7. Growth rate of PES strain on different $\mathrm{pH}$ values.

Table 3. Time (days) required by the different strains to reach maximum colony diameter $(8.5 \mathrm{~cm})$ depending on the $\mathrm{pH}$ of agar plates. $\mathrm{C}: \mathrm{K} 357$ $P$. ostreatus hybrid control.

\begin{tabular}{|c|c|c|c|c|c|c|c|c|c|c|c|}
\hline Strain/pH & $\mathbf{4}$ & $\mathbf{4 . 5}$ & $\mathbf{5}$ & $\mathbf{5 . 5}$ & $\mathbf{6}$ & $\mathbf{6 . 5}$ & $\mathbf{7}$ & $\mathbf{7 . 5}$ & $\mathbf{8}$ & $\mathbf{8 . 5}$ & $\mathbf{9}$ \\
\hline PEA & 14 & 14 & 14 & 13 & 13 & 13 & 11 & $\mathbf{8}$ & 11 & 10 & 11 \\
\hline PEC & 17 & 11 & 9 & 10 & 9 & $\mathbf{8}$ & $\mathbf{8}$ & $\mathbf{8}$ & $\mathbf{8}$ & 9 & 9 \\
\hline PEG & 14 & $\mathbf{1 3}$ & 14 & 14 & 14 & 17 & 14 & 14 & 14 & 14 & 14 \\
\hline PEF & 17 & 14 & 14 & 14 & 13 & 13 & 15 & $\mathbf{1 1}$ & 14 & $\mathbf{1 1}$ & $\mathbf{1 1}$ \\
\hline PEFi & 11 & 11 & 10 & 10 & 10 & 10 & $\mathbf{8}$ & $\mathbf{8}$ & $\mathbf{8}$ & 9 & 9 \\
\hline PEL & 14 & 14 & 14 & 14 & 14 & $\mathbf{1 3}$ & 14 & 14 & 14 & 17 & 16 \\
\hline PEP & $\mathbf{1 7}$ & $\mathbf{1 7}$ & 19 & 22 & 22 & 22 & 22 & 22 & 22 & 22 & 22 \\
\hline PES & 18 & 17 & 17 & 17 & 15 & 14 & 13 & 13 & $\mathbf{1 1}$ & $\mathbf{1 1}$ & $\mathbf{1 1}$ \\
\hline PE-SZM & 14 & 14 & $\mathbf{1 1}$ & 14 & 13 & 13 & 13 & 13 & 13 & 13 & 14 \\
\hline PLE 1V & 14 & 11 & 10 & 10 & 10 & 10 & 10 & $\mathbf{9}$ & 11 & 10 & 10 \\
\hline PLE 2V & 11 & $\mathbf{9}$ & $\mathbf{9}$ & 10 & 11 & 13 & 10 & 10 & $\mathbf{9}$ & $\mathbf{9}$ & 11 \\
\hline PLE 3V & 14 & $\mathbf{1 1}$ & $\mathbf{1 1}$ & 13 & 13 & 14 & $\mathbf{1 1}$ & $\mathbf{1 1}$ & $\mathbf{1 1}$ & $\mathbf{1 1}$ & $\mathbf{1 1}$ \\
\hline PLE 4V & 14 & 11 & 11 & 13 & 11 & 13 & 11 & 11 & 11 & $\mathbf{1 0}$ & 11 \\
\hline PLE 5V & 14 & 14 & 14 & 13 & 13 & 13 & 13 & 16 & 16 & $\mathbf{1 1}$ & 17 \\
\hline PLE 6V & 14 & 14 & 14 & 13 & 14 & 13 & 13 & $\mathbf{1 1}$ & $\mathbf{1 1}$ & 13 & 14 \\
\hline C (P.o.) & 9 & 9 & 9 & 9 & 9 & 9 & 8 & 8 & 8 & 8 & 9 \\
\hline Mean & 14.47 & 13.00 & 12.73 & 13.33 & 13.00 & 13.27 & 12.40 & 11.93 & 12.27 & 12.00 & 12.73 \\
\hline Deviation & 2.031 & 2.299 & 2.915 & 3.109 & 3.047 & 3.173 & 3.397 & 3.693 & 3.535 & 3.525 & 3.515 \\
\hline Prevalence & 1 & 4 & 3 & 0 & 0 & 2 & 3 & 7 & 6 & 6 & 3 \\
\hline
\end{tabular}

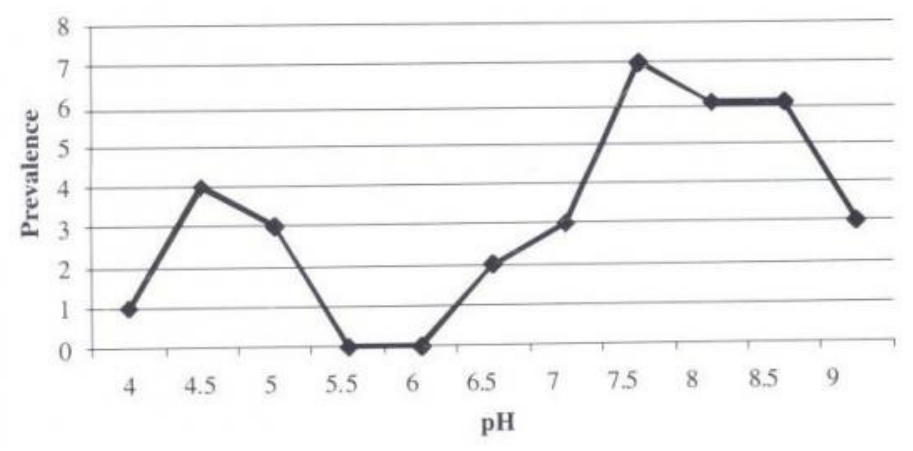

Figure 8. Average optimum $\mathrm{pH}$ values of 15 P. eryngii strains.

The light/dark experiments showed that incubation in dark enhanced the growth rate of mycelia of each strain, though we found significant differences between the strains. These results can be useful in mass production, because cultivation in black bags or in dark decreases the spawn run time. The most remarkable difference was found at the slowest growing PEP strain (Figure 9).

However, from the pinning period this strain requires light in the reproductive phase, as well, as described by Kalmár in 1960. In his experiments $P$. eryngii was grown in cellar and the fruiting bodies were immature and misshapen.

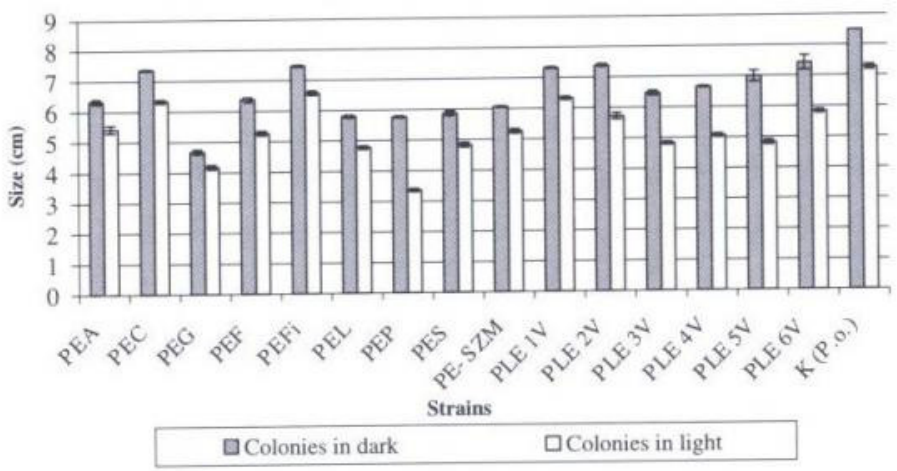

Figure 9. Growth of P. eryngii strains in light and dark.

When grown in dark the average size of the colonies was $6.53 \mathrm{~cm}$, while in light only $5.24 \mathrm{~cm}$. The same difference was found when the smallest colony sizes were compared: in dark $4.67 \mathrm{~cm}$ and in light $3.37 \mathrm{~cm}$. The strains showing the fastest growth reached $7.47 \mathrm{~cm}$ colony diameter in dark and only $6.57 \mathrm{~cm}$ in light. There were no significant differences between the growth rate deviation of the colonies, only 0.03 was measured (Table 4).

Table 4. Growth of colonies in light and dark.

\begin{tabular}{|l|c|c|}
\hline $\begin{array}{l}\text { Attributes of the } \\
\text { species based on } \\
\text { the growth of strains }\end{array}$ & $\begin{array}{c}\text { Growth in dark } \\
(\mathbf{c m})\end{array}$ & $\begin{array}{c}\text { Growth in light } \\
(\mathbf{c m})\end{array}$ \\
\hline Average size & 6.53 & 5.24 \\
\hline Smallest size & 4.67 & 3.37 \\
\hline Largest size & 7.47 & 6.57 \\
\hline Standard deviation & 0.82 & 0.85 \\
\hline
\end{tabular}

The value of the Spearman's rank correlation coefficient is 0.842 , which shows that growth rate of the 15 strains in light and dark are very similar; though there is some deviation between the growth rate in light and dark it is not significant. In addition to this, the co-existing is significant, which can be accepted at least at 0.01 significance-level (Table 5).

Table 5. Correlations between growth rates in light and dark.

\begin{tabular}{|c|c|c|c|c|}
\hline \multirow{7}{*}{$\begin{array}{c}\text { Spearman's } \\
\text { rho }\end{array}$} & & & dark & light \\
\hline & \multirow[t]{3}{*}{ dark } & Correlation Coefficient & 1.000 & $0.842(* *)$ \\
\hline & & Sig. (2-tailed) & & 0.000 \\
\hline & & $\mathrm{N}$ & 15 & 15 \\
\hline & \multirow[t]{3}{*}{ light } & Correlation Coefficient & $0.842(* *)$ & 1.000 \\
\hline & & Sig. (2-tailed) & 0.000 & \\
\hline & & $\mathrm{N}$ & 15 & 15 \\
\hline
\end{tabular}

** Correlation is significant at the 0.01 level (2-tailed).

Mycelial dry mass: mycelial mass results obtained in the cellofane tests showed mean correlation with the colony diameters measured in the mycelium growing tests after 14 days of incubation on $25^{\circ} \mathrm{C}$ (Figure 10-11 and Table 6-7). The deviation may be explained by the different density of aerial hyphae and mycelia of the various strains. This fact 
points at the unreliability of strain selection that was done solely on the score of the colony diameter. Therefore, it is advised to take other parameters into account in addition to the colony diameter in the course of the strain selection.

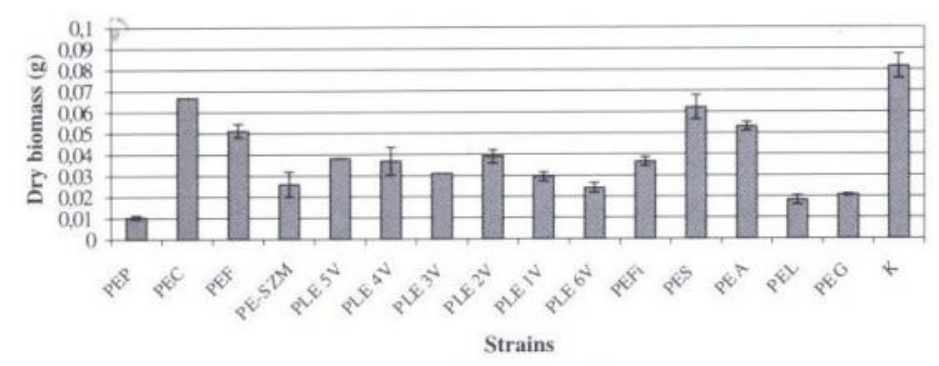

Figure 10. Biomass productions of different strains.

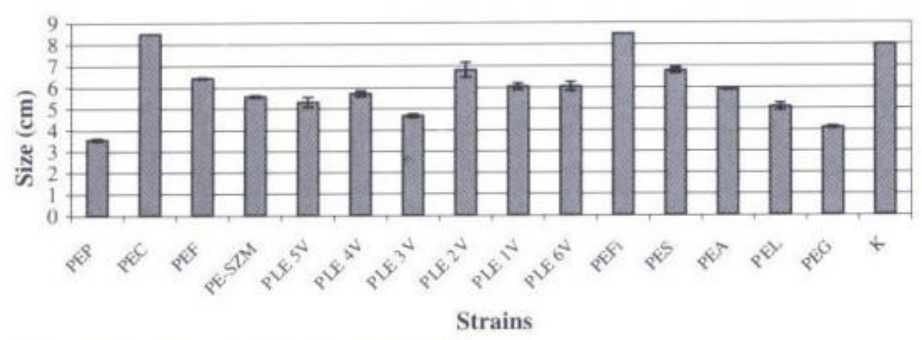

Figure 11. Growth of strains on $25^{\circ} \mathrm{C}$.

Table 6. Features of the P. eryngii species on the basis of the growth of strains, in point of biomass volume.

\begin{tabular}{|l|c|}
\hline $\begin{array}{l}\text { Attributes of the species based } \\
\text { on the growth of strains }\end{array}$ & $\begin{array}{c}\text { Volume of biomass on } \\
\mathbf{2 5} \mathbf{~}^{\circ} \mathbf{C}(\mathbf{g})\end{array}$ \\
\hline Average size & 0.0363 \\
\hline Smallest size & 0.0104 \\
\hline Largest size & 0.0669 \\
\hline Standard deviation & 0.0162 \\
\hline
\end{tabular}

Table 7. Features of the P. eryngii species (colony diameter) on the basis of the growth of strains on $25^{\circ} \mathrm{C}$.

\begin{tabular}{|l|c|}
\hline $\begin{array}{l}\text { Attributes of the species based } \\
\text { on the growth of strains }\end{array}$ & $\begin{array}{c}\text { Colony diameter on } \\
\mathbf{2 5}{ }^{\circ} \mathbf{C}(\mathbf{c m})\end{array}$ \\
\hline Average size & 5.93 \\
\hline Smallest size & 3.56 \\
\hline Largest size & 8.5 \\
\hline Standard deviation & 1.38 \\
\hline
\end{tabular}

Table 8. Correlations of growth rates in light and dark.

\begin{tabular}{|c|c|c|c|c|}
\hline \multirow{4}{*}{$\begin{array}{c}\text { Spearman's } \\
\text { rho }\end{array}$} & Biomass & Correlation Coefficient & 1.000 & $0.696(* *)$ \\
\cline { 3 - 5 } & & Sig. (2-tailed) & & 0.004 \\
\cline { 2 - 5 } & Growth & $\mathrm{N}$ & 15 & 15 \\
\cline { 3 - 5 } & & Correlation Coefficient & $0.696(* *)$ & 1.000 \\
\cline { 3 - 5 } & & Sig. (2-tailed) & 0.004 & \\
\cline { 3 - 5 } & & $\mathrm{N}$ & 15 & 15 \\
\hline
\end{tabular}

** Correlation is significant at the 0.01 level (2-tailed).

Though mushrooms are obligate aerobic organisms, it can be stated about the anaerobic tolerance of the strains, that one week of incubation without oxygen did not have any effect on their viability and strain specific growth rate. The growth rate continuously decreased during the incubation. The high anaerobic tolerance level plays an important part in the successful spawn run of airless substrate (Figure 12).

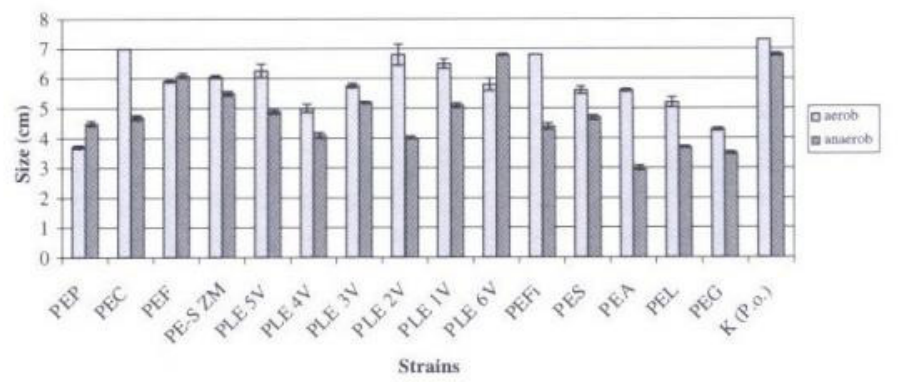

Figure 12. Growth of strains under aerobic and anaerobic atmospheric conditions.

Most of the strains showed better growing activities under aerobic atmospheric conditions, but three strains (PEP, PEF and PLE 6V) could grow better under anaerobic atmosphere and two of these three strains (PEP and PLE 6V) produced significantly larger colony diameter.

Under aerobic atmosphere the average growth of colonies was $5.75 \mathrm{~cm}$, whereas under anaerobic conditions only 4.7 $\mathrm{cm}$. Deviation of growth was not remarkable even at extreme values, since the smallest sizes of under aerobic and anaerobic conditions were 3.71 and $3.17 \mathrm{~cm}$, respectively. Strains that produced the largest growth reached $6.8 \mathrm{~cm}$ colony diameter both under aerobic and anaerobic conditions. There was no remarkable difference between the standard deviation of the growth of colonies under aerobic/anaerobic conditions, only 0.07 deviation was measured (Table 9).

Table 9. Growth of colonies under aerobic and anaerobic atmospheric conditions.

\begin{tabular}{|l|c|c|}
\hline $\begin{array}{l}\text { Attributes of the species } \\
\text { based on the growth of } \\
\text { strains }\end{array}$ & $\begin{array}{c}\text { Aerobic growth } \\
\text { (cm) }\end{array}$ & $\begin{array}{c}\text { Anaerobic growth } \\
\text { (cm) }\end{array}$ \\
\hline Average size & 5.75 & 4.7 \\
\hline Smallest size & 3.71 & 3.17 \\
\hline Largest size & 6.8 & 6.87 \\
\hline Standard deviation & 0.92 & 0.99 \\
\hline
\end{tabular}

According to the Spearman's rank correlation there was a loose connection $(0.322)$ between the aerobic and anaerobic conditions, so the two conditions did not determine the growth rate (Table 10). Certain strains grew better under aerobic, whereas others grew better under anaerobic conditions at $\mathrm{pH} 6$.

Table 10. Correlations between growths under aerobic and anaerobic conditions.

\begin{tabular}{|c|c|c|c|c|}
\hline \multirow{7}{*}{$\begin{array}{c}\text { Spearman's } \\
\text { rho }\end{array}$} & & & Aerobic & Anaerobic \\
\hline & \multirow[t]{3}{*}{ Aerobic } & Correlation Coefficient & 1.000 & 0.322 \\
\hline & & Sig. (2-tailed) & . & 0.242 \\
\hline & & $\mathrm{N}$ & 15 & 15 \\
\hline & \multirow[t]{3}{*}{ Anaerobic } & Correlation Coefficient & 0.322 & 1.000 \\
\hline & & Sig. (2-tailed) & 0.242 & . \\
\hline & & $\mathrm{N}$ & 15 & 15 \\
\hline
\end{tabular}




\section{Summary}

In present research 15 wild $P$. eryngii strains of Hungarian origin and one $P$. ostreatus industrial hybrid were used in order to determine in vitro the growth rate of the vegetative mycelia of the species and the different strains, under various environmental conditions. We aimed to reveal the growth rate differences between the various strains of $P$. eryngii and the industrial K 357 P. ostreatus hybrid, depending on the environmental conditions.

Growth rate of the various $P$. eryngii strains was very diverse, in respect to the determinate values of the environmental factors. On the basis of the average growth rate of the strains, we could conclude what are the optimum ecological values of the species, though these conclusions did not always coincide with the optimum values of the certain strains.

\section{Acknowledgements}

Many thank to Attila Kiss, manager-director of the EGERFOOD Regional Knowledge Centre (Eger) for his support in order to perform and complete the experiments, to Károly Pál, Márta Váradi-Szarvas and Mária Kadlott-Hilyák for their work and active help in the experiments and to Gabriella Soós for her help in the statistical processing of the data.

\section{References}

Boisselier-Dubayle, M.-C. 1983: Taxonomic significance of enzyme polymorphism among isolates of Pleurotus (Basidiomycetes) from Umbellifers. Trans Br Mycol Soc., 81: 121-127.

Bresinsky, A., Fischer, M., Meixner, B. \& Paulus, W. 1987: Speciation in Pleurotus. Mycologia, 83: 736-742.

Cailleux, R. \& Diop, A. 1974: Recherches expérimentales sur les conditions d'ambiance requises pour la fructification du Pleurotus eryngii et de l'Agrocybe aegerita. Mushroom Sci., IX (Part I.): 607-619.

Gerhardt, E. 2007: Gombászok kézikönyve, Pozkal-Inowroclaw, Lengyelország (Hungarian translation by Cs. Locsmándi) p. 218.

Geösel A., Györfi J. \& Vetter J. 2009: Az Agaricus subrufescens termesztése és ásványielem-összetétele. Mikológiai közlemények: Clusiana, 2009. (48. évf.) 1. sz. 25-35, 113-114. old.

Győrfi, J. \& Hajdú, Cs. 2007: Casing-material experiments with Pleurotus eryngii. International Journal of Horticultural Science, 2: 33-36.

Hilber, O. 1982: Die Gattung Pleurotus (Fr.) Kummer unter besonderer Berücksichtigung des Pleurotus eryngii Formenkomplexes. Bibliotheca Mycologica, 87.
Joly, P., Cailleux, R. \& Cerceau, M. 1990: La stérilité male pathologique, élément de la co-adaptation entre populations de champignons et de plantes-hotes: modéle des Pleurotes des Ombelliféres. Bull Soc Bot Fr., 137: 71-85.

Kalmár, Z. 1960: Termesztési kísérletek ördögszekér laskagombával. Kísérletügyi Közlemények, Kertészet, 52/c, 4: 119-125.

Kirbag, S. \& Akyuz, M. 2008: Effect of various agro-residues on growing periods, yield and biological efficiency of Pleurotus eryngii. Journal of Food, Agriculture and Environ., 6: 402-405.

Kószó, S. 1997: Az ördögszekér laskagomba (Pleurotus eryngii) termesztése, Magyar Gomba, 2: 12-13.

Lewinsohn, D., Wasser, S. P., Reshetnikov, S. V., Hadar, Y. \& Nevo, E. 2002. The Pleurotus eryngii species-complex in Israel: distribution and morphological description of a new taxon. Mycotaxon, 81: 51-67.

Ohga, S. (2000): Influence of wood species on the swadust base cultivation of Pleurotus abalonusa and Pleurotus eryngii. J. Wood Sci., 46: 175-197.

Ohga, S. (1999): Suitability of bambo powder for the sawdustbased ultivation of edible mushroom. Mushroom Sci. Biotechnocol., 7: 19-22.

Ohga, S. \& Royse, D.J. (2004): Cultivation of Pleurotus eryngii. on ubbrella plant (Cyperus alternifolius) substrate. J. Wood Sci., 50: 466-469.

Orbán S. 1995: Biometria, kézirat, EKF Nyomda, p. 50-59.

Rodriguez Estrada, A. E. 2008: Molecular phylogeny and increases of yield the antioxidants selenium and ergothioneine in Basidiomata Pleurotus eryngii, Dissertation, The Pennsylvania State University, Department of Plant Pathology.

Stamets, P. 2000: Growing Gourmet and Medicinal Mushrooms. Ten Speed Press, Berkeley, p. 301-304.

Szarvas, J. \& Szarvas, G. 2002: Az ördögszekér laskagomba (Pleurotus eryngii) termesztése. Magyar Gombahiradó, 36: p. 6-7.

Sawa, S. (2000): Cultivation caracteristic of Pleurotus eryngii. (in Japanese). Bull. Aichi. For. Res. Cent. 33: 41-46.

Szili, I. 1994: Gombatermesztés. Mezögazda Kiadó, Budapest, pp. 143-144.

Venturella, G. 2000: Typification of Pleurotus nebrodensis. Mycotaxon, 75: 229-231.

Véssey, E. 1971: Adatok az ördögszekér laskagomba termesztéséhez. Mikológiai Közlemények, 3: 121-131.

Zervakis, G., Venturella, G. \& Papadopoulou, K. 2001: Genetic polymorphism and taxonomic infrastructure of the Pleurotus eryngii species-complex as determined by RAPD analysis, izoenzyme profiles and ecomorphological characters. Microbiology, (2001), 147: 3183-3194.

Zervakis, G. \& Balis, C. 1996: A pluralistic approach in the study of Pleurrotus species with emphasis on compatibility and physiology of the European morphotaxa. Mycol. Res., 100: 717-731. 